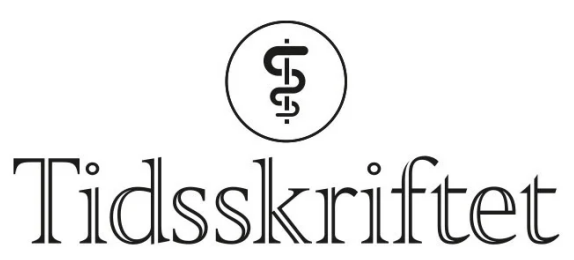

DEN NORSKE LEGEFORENING

\title{
Lisbeth Hansen
}

MINNEORD

KATHRINE AGLEN SEEBERG

INGER MARIE VEIBY

INGVILD HALLBERG

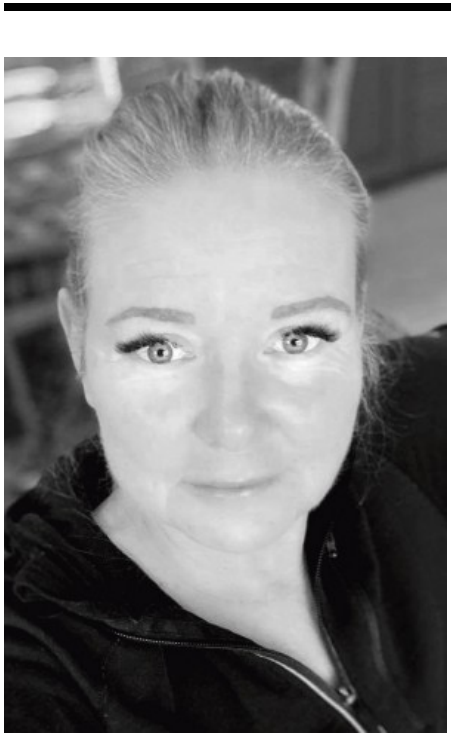

Vår kjære allmennpraktiserende kollega og venninne Lisbeth Hansen døde av kreftsykdom 17. juni 2020, bare 48 år gammel. Kollegaer, familie og venner står igjen med et dypt savn.

Lisbeth vokste opp i Vestby i Akershus med en storesøster og foreldre.

Etter gymnaset fulgte hun i sin fars fotspor og begynte på sivilingeniørstudiet i kjemi ved NTNU i Trondheim. Halvveis i studiet erkjente hun at det var en annen vei hun ville gå og begynte på medisinstudiet ved Universitetet i Oslo i 1995.

Lisbeth var en person med enorm kapasitet. Ved siden av studiene var hun engasjert $\mathrm{i}$ studentforeningen MSO (Medisinernes seksualopplysning). Hun fikk jobberfaring mens hun studerte. På Gaustad psykiatriske sykehus var hun til glede for pasienter og kollegaer i flere år. Seinere jobbet hun ved ambulansetjenesten i Oslo. Også her gjorde hun inntrykk på sine kollegaer som en entusiastisk medarbeider. 
Turnustjenesten gjennomførte hun ved sykehuset i Bærum, med distriktstjeneste i Nittedal. Akuttmedisin lå hennes hjerte nær. Etter turnus begynte hun å jobbe ved anestesiavdelingen på sykehuset i Gjøvik, deretter i Drammen. Det ble krevende å kombinere denne vaktbelastende spesialiteten med familieliv. I alle fall for Lisbeth, som aldri gjorde noe halvveis. Hun bosatte seg på Nesodden og praktiserte som fastlege, i tillegg til å være kommunelege i noen år. Som fastlege var hun grundig, tydelig og omsorgsfull. Strukturerte arbeidsdager gav rom for å følge opp barna på skolen og på fotballbanen, med ulike verv. Hun var enormt stolt av guttene sine.

Det var lett å bli fascinert av Lisbeth. Hun hadde et ærlig og tilstedeværende vesen. Var du like ærlig og lojal tilbake, fikk du en venn for livet. Hun var uredd for det meste. Det var aldri stille rundt henne. Som oftest ledet hun samtalen, men var likevel en som kunne lytte.

Vi delte viktige studieår og har alle våre personlige minner og historier om Lisbeth som vi bærer videre. Opp igjennom årene har vi holdt kontakt, fulgt med på hverandres utvikling både faglig og sosialt. Vi lot oss virkelig imponere av Lisbeths løping de seinere årene, med åttemilsløp på merittlisten.

Vi er mange som vil savne Lisbeth. Våre tanker går til Jan Tore, Sondre og Storm Gustav, som har mistet sin store kjærlighet og sin mor.

Vi takker for alle gode minner og minnes henne med kjærlighet.

På vegne av studievenner fra PK-95

Publisert: 7. september 2020. Tidsskr Nor Legeforen. DOI: 10.4045/tidsskr.20.0594

(C) Tidsskrift for Den norske legeforening 2023. Lastet ned fra tidsskriftet.no 26. april 2023. 